\section{BIBLIOTECA \\ JORGE D. WLLIAN :}

1974 JOURNAL OF HERPETOLOGY 8(1):71-75
COLECCION HERPETOLOGICA
Y BIBLIOTECA

Dr. José Miguel Cei

\title{
Two New Species of Ctenoblepharis (Reptilia, Iguanidae) from the Arid Environments of the Central Argentina (Mendoza Province)
}

\author{
J. M. Cei \\ Instituto Biologia Animal \\ Universidad Nacional de Cuyo, Mendoza, Argentina
}

ABSTRACT-Two new species of the iguanid genus Ctenoblepharis, C. donoso barrosi and C. rabinoi, are described, on the basis of adult specimens collected from the arid lands of the southeastern Mendoza province, Argentina. General notes on the geographical distribution and ecological features of the genus are included.

The genus Ctenoblepharis was proposed by Tschudi (1845) for the species adspersus, from the coastal desert of Peru (from Huacho south). The genus is allied to Liolaemus (multiformis group); Phrynosaura Werner (1907) and Helocephalus Philippi (1860) are synonymous (Donoso-Barros, $1966,1971,1972)$. Nine species of Ctenoblepharis have been described. Their taxonomic features and distribution are pointed out by Donoso-Barros (1958) and in the recent catalogue and key of the Neotropical Squamata by Peters and Donoso-Barros (1970) under the generic names of Ctenoblepharis and Phrynosaura. They look like prevalent andean forms such as jamesi Boulenger (1891), nigriceps (Philippi, 1860), schmidti Marx (1960), stolzmanni Steindachner (1891) and reichei (Werner, 1907), all from the Cordillera of Atacama, Antofagasta or Tarapaca, extending both in Chilean or Bolivian highlands northwards to Peru. Ctenoblepharis marmorata (Burmeister, 1861) lies in desert areas of Catamarca (Argentina); C. werneri (Muller, 1928) is an inhabitant of the sandy flats of La Rioja, San Juan and La Pampa (Argentina). Liolaemus anomalus Koslowsky (1895) from the mountains of La Rioja (Argentina), was also added to Ctenoblepharis by DonosoBarros (1969), (Fig. 1).

During our recent field trips in the little known southeastern territories of the Mendoza Province (Argentina), two new species, Ctenoblepharis rabinoi sp.nov. and

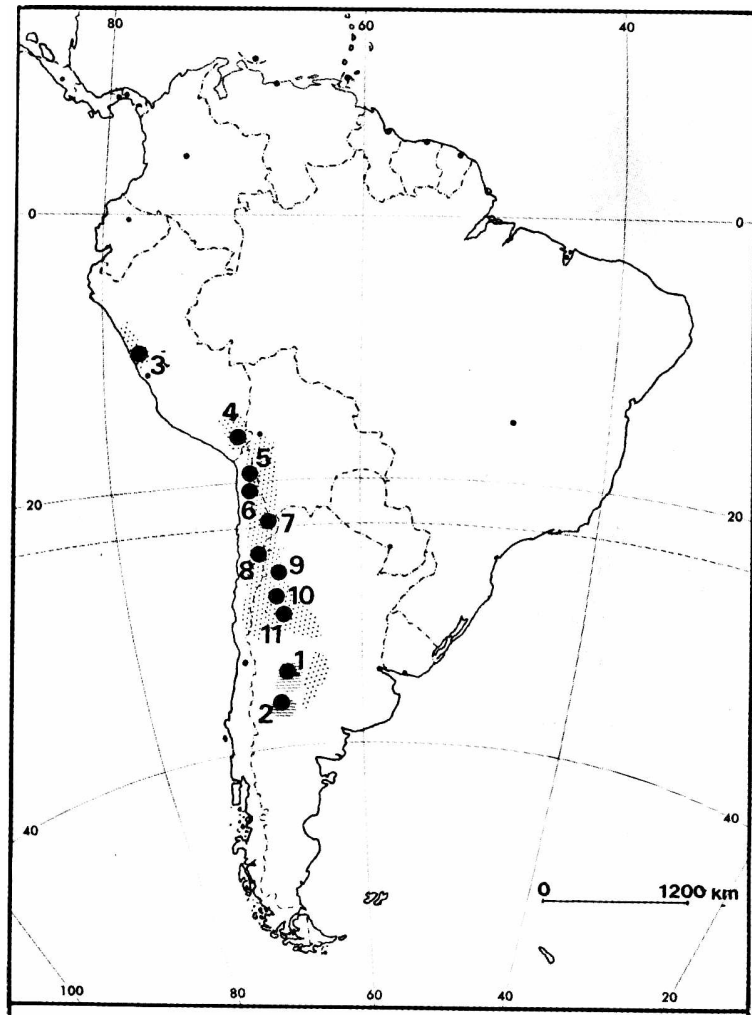

FIGURE 1. Distribution of the reported species of the genus Ctenoblepharis. Hatched areas: 1-Ctenoblepharis rabinoi; 2-C. donoso barrosi. Stippled areas: $3-C$. adspersus; 4-C. stolzmanni; 5-C. jamesi; 6-C. reichei; 7-C. schmidti; 8-C. nigriceps; 9-C. marmorata; 10-C. anomalus; $11-C$. werneri. Black circles indicate the type localities of the species; type locality of $C$. werneri is only approximated. 
Ctenoblepharis donoso barrosi sp.nov., have been discovered. Their extra-andean distribution and ecological trends are discussed. The specimens belong to the Herpetological Collection of the Instituto Biologia Animal, Universidad Nacional de Cuyo, Mendoza (IBA.UNC).

\section{Ctenoblepharis donoso barrosi sp.nov.}

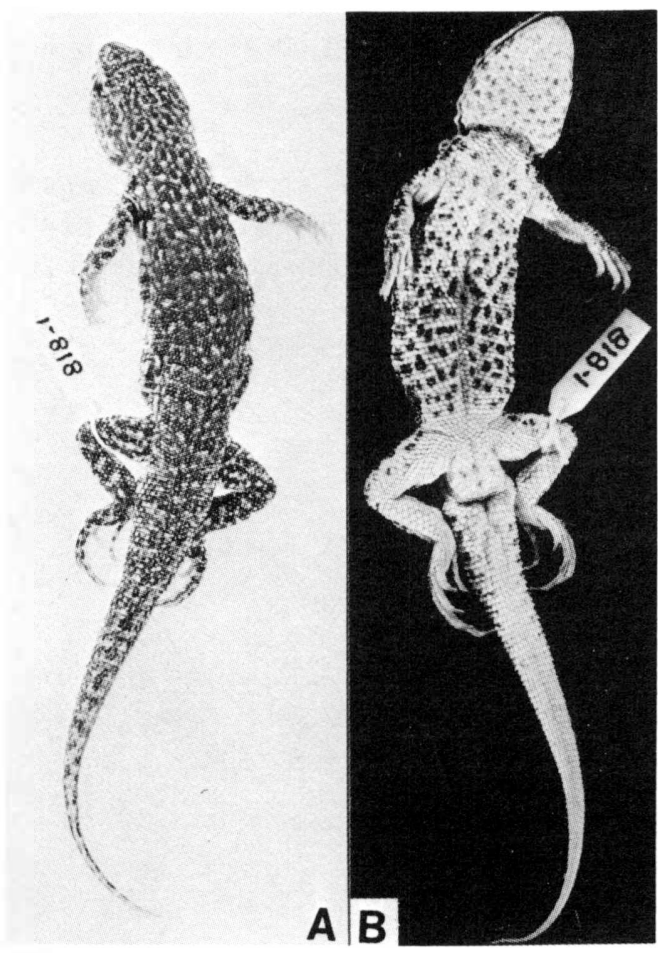

FIGURE 3. A, B-Ctenoblepharis rabinoi sp. nov.
Holotype.-IBA. UNC. 824-1. An adult female from Matancilla salt sandhills $(1000 \mathrm{~m})$, Mendoza Province, Argentina, collected December 1972 by J. M. Cei, L. P. Castro and T. Ferreyra. (Fig. 2 A,B).

Paratype.-IBA. UNC. 824-2. The same locality and data as holotype.

Diagnosis. -A new somewhat anomalous Ctenoblepharis, with protruding jaw not evident, slender body, long tail, a single series of scales between labials and subocular; head scales strongly differentiated; small dorsal scales, slightly carinate $184-88$ around middle of body); dorsum gray with regular semilunar spots. locality.

Distribution.-Known from the type

Description of holotype.-A female, snout-vent $60 \mathrm{~mm}$, tail $84 \mathrm{~mm}$, head length $14 \mathrm{~mm}$, head width $11 \mathrm{~mm}$, hind leg $37 \mathrm{~mm}$, fore leg $24 \mathrm{~mm}$. General aspect slender, the adpressed hind limb reaches the shoulder; tail longer than the head plus body; head stout, with a non protruding jaw; cheeks prominent; neck narrower than head, with lateral folds; gular fold absent. Head scales highly differentiated; rostral broad, twice longer than high; 3

internasals; shields between nasals and frontals enlarged; one azygous frontal separated from the interparietal by 2 pairs of frontoparietals; parietals larger than the interparietals; 8 supraoculars enlarged; subocular elongate, separated from the supralabials by a single series of scales; 7 supralabials and 6 infralabials; temporal scales convex, smooth and enlarged; eyelids fringed; ear opening vertically extended; side of the neck with strong conical granules; lateral sides of the neck folded. Dorsal scales convex, slightly mucronate, smaller than ventrals, juxtaposed or subimbricate; lateral scales smaller than dorsals, almost granular; ventral scales quadrangular, smooth, subimbricate or juxtaposed; caudal scales irregular, elongate or enlarged, slightly keeled at the end of the tail; limb scales enlarged, smooth, granular on the inner side and on the ventral surface of the arm; 88 scales around the middle of body; 22 lamellae slightly carinate under the fourth toe; length of head corresponding to the length of 26 middorsal scales. Dorsal ground bluish-gray, with 7 transversal series of semilunar black spots (4 for each series), white-bordered posteriorly; tail with 15 series of converging dorsal black spots; ventral surface white, marbled by diluted grayish spots, darken on throat and tail.

Description and measurements $(\mathrm{mm})$ of paratype.-A female snout-vent 63; tail regenerated; head length 15; head width 12, hind leg 39, fore leg 24.5. Somatic characters as the holotype. 84 scales around middle of body.

Remarks. -A psammophilous lizard, living in sandy embossments alongside the small salt clay lagoons, scattered in the basaltic eastern flats neighboring the Volcan Payun plateau, at some $1000 \mathrm{~m}$. The reproduction and ecology are still unknown. This new species is easily 
differentiated from all the known Ctenoblepharis: from jamesi-stolzmanni by the dorsal scales smaller than ventrals and by more than 55 scales around middle of body; from species name by the strongly differentiated head scales; from nigriceps by the head color; from schmidti by the dorsal pattern and the general aspect of body and limbs; from anomalus by the dorsal color and the scales, unkeeled on limbs and body; from werneri by the rows of scales between subocular and supralabials and the general aspect of body; from marmoratus by the ventral unkeeled scales on tail; from reichei by the non protruding jaw, the lepidosis and a very different coloration. Ctenoblepharis donoso barrosi and C. reichei are the only species of the genus with slightly carinate lamellae under the fourth toe. The species is dedicated to $\mathrm{Dr}$. R. DonosoBarros who has contributed much to our knowledge of the genus Ctenoblepharis.

\section{Ctenoblepharis rabinoi sp.nov.}

Holotype,-IBA.UNC. 818-1. An adult male from the sandy shores of Nihuil Dam $(1800 \mathrm{~m})$, Mendoza Province, Argentina, collected December 1972 by M. Rabino (Fig. $3 A, B$ ).

Paratype.-IBA. UNC. 818-2. The same locality and data as holotype.

Diagnosis. - A new species of Ctenoblepharis with clearly protruding jaw (Fig. 4), slender body, moderate tail, high number of series of scales between labials and subocular, small dorsal scales (74-78 around middle of body), dorsum dark profusely crossed by irregular bands of whitish spots.

Distribution.-Known only from type locality.

Description of holotype. A male specimen, snout-vent $60 \mathrm{~mm}$, tail $61 \mathrm{~mm}$, head length $16 \mathrm{~mm}$, head width $13 \mathrm{~mm}$, hind leg $35 \mathrm{~mm}$, fore leg $22 \mathrm{~mm}$. General aspect slender; the adpressed hind limb reaches the axilla; tail as long as the length of head and body; head depressed, elongate, with a very characteristic flattened protruding jaw; checks prominent; neck narrower than head, with pronounced gular folds, laterally expanded in short folds.

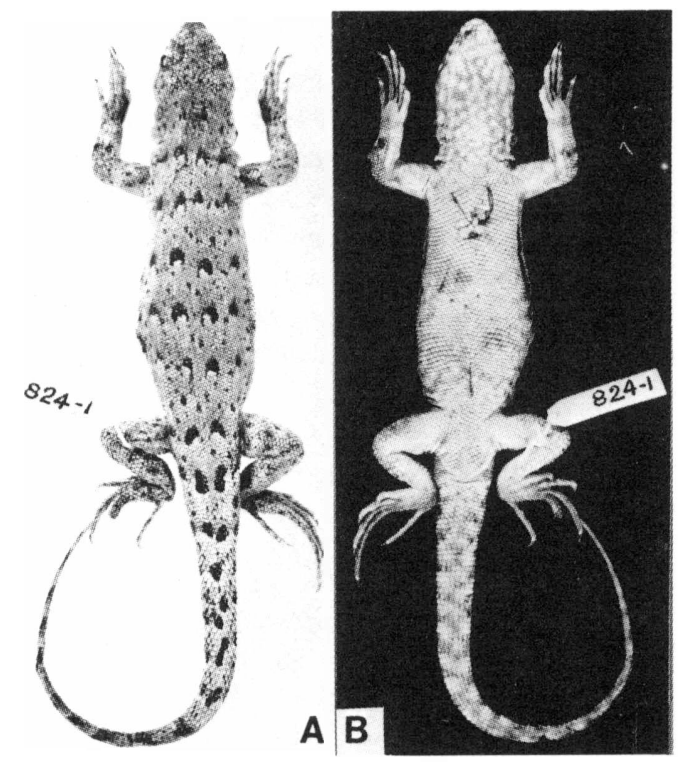

FIGURE 2. A, B-Ctenoblepharis donosc barrosi sp nov

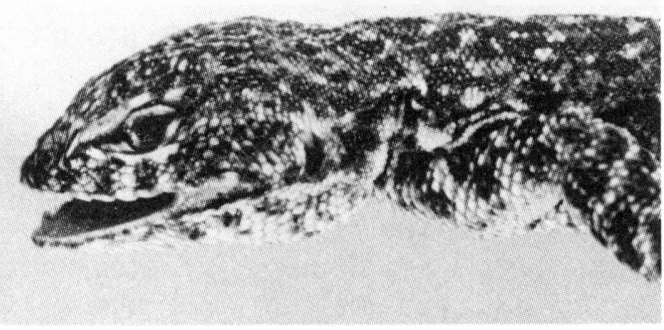

FIGURE 4. Head of Ctenoblepharis rabinoi lateral view and protruding jaw. Head scales slightly differentiated; rostral subtriangular and narrow, limited by 4 small scales; frontals irregular, separated from the interparietal by 4 small frontoparietals; parietals smaller than interparietal; 5 or 6 irregular supraoculars on each side, near to the interorbital shields; subocular elongate, separated from the supralabials by 2 or 3 series of scales; 8-10 supralabials and 8 infralabials, temporal scales smooth, enlarged; palpebral frings well developed; ear opening small, vertically extended; sides of the neck granulated, plicate, laterally projected in a strong longitudinal antehumeral fold. Dorsal scales convex, 
smaller than ventrals, smooth and juxtaposed; lateral scales slightly smaller than dorsals, almost granular; ventral scales quadrangular, smooth, imbricate, twice size of dorsals; caudal scales dorsally enlarged, trapezoidal, slightly keeled at base of the tail, elsewhere carinate, smooth, quadrangular or trapezoidal on lower surface; limb scales enlarged, softly carinate, sharply pointed on the external side; posterior surface of thigh granular; 78 scales around middle of body; 6 preanal pores; 24 lamellae not carinate under fourth toe; length of the head corresponding to the length of 29 middorsal scales. Ground color black or grayish, with transverse profuse white spots, forming white-bordered dark marks on dorsum and tail. Head and limbs mottled by irregular white and black spots; ventral surface white, speckled by rounded black spots, darker on the belly; ventral surface of tail and limbs immaculate.

Description and measurements $(\mathrm{mm})$ of paratype.-A male specimen snout-vent 51 ; tail 50; head length 13.5; head width 10.5; hind leg 33; fore leg 19. Somatic and pigmentary characters as the holotype. 74 scales around middle of body.

Remarks. - The present new species is quite different from all the reported Ctenoblepharis. It is clearly different from jamesi and stolzmanni for the dorsal scales are smaller than ventrals and for the number of scales around middle of body is more than 55; from adspersus, because of its more differentiated head scales; from nigriceps for the head color and the number of the scales around middle of body, fewer than 90; from schmidti for the dorsal and ventral pattern and the number of the series of scales between labials and subocular; from anomalus for the general pattern, the fewer number of scales around middle body, the limb scales softly carinate, not keeled, and the higher number of series of scales between labials and subocular. However the general aspect and the series of scales between labials and subocular scales (2-3 series) are quite similar with $C$. anomalus, (1-2 series). The other species of Ctenoblepharis, except werneri, have single series of scales, but werneri is a completely different lizard, for general aspect, lepidosis and coloration. C. rabinoi is apparently a rare lizard. It lives in the coastal dunes alongside the sinuous southern Nihuil Dam (Atuel River), in the rocky landscape of the Mendoza Province. They are rapid and fossorial animals, burrowing so quickly in sandy environment, that they are not easily seen or found in their natural habitat. The species is dedicated to Mr. Rabino, who discovered this lizard, giving some preliminary data about its ecology and behavior.

\section{GENERAL CONSIDERATIONS}

The above described species extend the distribution of Ctenoblepharis (Fig. 1). Instead of an Andean range, it is evident that an earlier stock of these iguanids spread widely on the ancient extra-andean pampean massif and attained there a noticeable level of morphological differentiation. The southern boundary of the genus is extended to latitude $37^{\circ} \mathrm{S}$ with $\mathrm{C}$. donoso barrosi and $C$. werneri. Ctenoblepharis nigriceps seems to cover a southernmost range (latitude $33^{\circ} \mathrm{S}$ ) in the arid precordilleran highlands facing Mendoza city (unpublished data). Ctenoblepharis is a significant line of evolution of the iguanid branch. The convergent color pattern of Ctenoblepharis donoso barrosi and Ctenoblepharis werneri is a very suggestive one in spite of their different morphology. Ecologically, the genus represents an adaptive tendency towards the sandy soil and the fossorial habits. Probably a number of adaptive trends of these lizards, such as the fringed eyelids or lepidosis, for example, could support the specialization for a psammophilous life.

\section{LITERATURE CITED}

Boulenger, G. A. 1891. Description of a new lizard of the genus Ctenoblepharis, from Chile. Proc. Zool. Soc. London, p.3. PI.I. 2 figs.

Burmeister G. 1861. Reise durch die La Plata Staaten 2:524.

Donoso-Barros, R. 1958. El género Ctenablepharis Tschudi, en Chile (Reptilia, Squamata, Iguanidae). Inv. Zool. Chil. 4:253-257. 
1966. Reptiles de Chile. Edic. Univ. de Chile, Bruckmann München: cxlvi + 458 pp.

1969. Consideraciones nomenclaturales sobre dos lagartijas argentinas. Bol. de la Soc. de Biología de Concepción-Chile 41:93-94.

1971. The genera Ctenoblepharis and Phrynosaura. Herp. Review 3(5):85.

1972. Contribución al conocimiento del género Ctenoblepharis Tschudi y Phrynosaura Werner (Sauria, Iguanidae). Bol. Soc. Concepción 44:129-134.

Koslowsky, J. 1895. Batracios y Reptiles de La Rioja y Catamarca. Rev. Mus. La Plata 6:333-344.

Marx, H. 1960. A new iguanid lizard of the genus Ctenoblepharis. Field. Zool. 39(37):407-409.

Muller, L. 1928. Herpetologische Mitteilungen. Zool. Anz. 77:61-84.

Peters, J. A. and R. Donoso-Barros. 1970. Catalogue of the Neotropical Squamata. Part II. Lizards and Amphisbaenians. United States Nat. Mus. Bull. 297.

Philippi, R. A. 1860. Reise durch die Wüste Atacama. Ed. Halle.

Steindachner, R. 1891. Über einige neuer und seltenere Reptilien und Amphibien. Kais. Ak. Wiss. Wien. Mathem. Naturwiss. 14:141-144.

Tschudi, J. J. von. 1845. Reptilium conspectus quae in Republica Peruana reperiuntur et pleraque observata vel collecta sunt in itinere. Arch. Naturgesch. 2(1):150-170.

Werner, F. 1907. (in Burger) Estudios sobre reptiles chilenos. Anales Universidad de Chile 121:149-155. 